\title{
Introduction: The Persianate Bazaar
}

\author{
Fahad Ahmad Bishara \\ University of Virginia, Charlottesville, Virginia, USA \\ bishara@virginia.edu
}

Nandini Chatterjee

University of Exeter, Exeter, UK

n.chatterjee@exeter.ac.uk

\begin{abstract}
The collection of essays in this volume examines forms of business documentation in the late Persianate world and the Indian Ocean, between the seventeenth and twentieth centuries. Looking upon business in its broadest sense, the themes range from property disputes within families to inter-polity and inter-imperial deals, all of which is captured within the notion of the bazaar. Presenting documents and documentary forms written in Persian, but also the associated languages of Arabic, Bengali, Gujarati, Hindi, Marathi and Rajasthani, the articles collectively enrich the idea of the Persianate, delineating its specific dispensations within regional contexts, and also its boundaries and limitations. This is also a contribution to the study of Persographia, in this case Persianate rather than just Persian writing. The articles study specific language combinations, lexical elements and usages that came to be deployed in different areas and the legal cultures they provide evidence for.
\end{abstract}

\section{Keywords}

Persianate world - Indian Ocean - documents - language - law - business

\section{Introduction}

The Persianate world is a term given to an enormous and now-disappeared cultural-linguistic zone first conceptualized by Marshall Hodgson in the 
1960s, ${ }^{1}$ which has become the subject of increased scholarly interest since the 2010s. $^{2}$ Defined simply in terms of language use, the Persianate world consists of those parts of the world where substantial and/or important groups of people used the Persian language ${ }^{3}$ for any historically significant length of time. However, the designation Persianate implies more than this; alongside language use, it indicates a shared repertoire of intellectual, political, religious and social concepts and practices. In this sense, the Persianate world was a cultural zone, a cosmopolis stretching from Bengal to Bosnia. Ultimately, the Persianate denotes the shared qualities of people: those whose movements, associations and conceptions of self were premised on the existence of the Persianate world. ${ }^{4}$

Defining the outer limits of this zone is a trickier matter, for up close, Persian language use was highly variable in terms of length of time, social depth and function. Mapping interactions with regional vernaculars (for example, Bengali, Chaghatai, Marathi) is analytically more straightforward (if not at all easy substantively); but doing so while acknowledging other, overlapping cosmopoleis is too complex to have been attempted even by the most gifted of scholars. ${ }^{5}$ The matter grows even more complicated should we consider linguistic and non-linguistic factors together; there is no clear agreement on exactly how and to what extent the Islamicate (the socio-cultural world touched by Islam, also as conceptualized by Hodgson), in all its cultural instantiations, overlaps with the Persianate, which is laden with pre- and non-Islamic cultural elements, not least the pre-Islamic royal traditions of Iran itself. The collection of papers presented here cannot provide an exhaustive map of these cultural

1 M.S. Hodgson, The Venture of Islam, vol. 2 (Chicago: Chicago University Press, 1974): 293.

2 A. Amanat and A. Ashraf, ed., The Persianate World: Rethinking a Shared Sphere (Leiden: Brill, 2018); N. Green, ed., The Persianate World: The Frontiers of a Eurasian Lingua Franca (Oakland: University of California Press, 2019); R. Eaton, India in the Persianate Age, 1000-1765 (London: Allen Lane, 2019); E. Flatt, The Courts of the Deccan Sultanates: Living Well in the Persian Cosmopolis (Cambridge: Cambridge University Press, 2019).

3 Specifically, New Persian, written in the modified Arabic script, which was standardized around the 9th century CE; supplanting Middle (Pahlavi) and Old Persian in everything but liturgical usage among the Zoroastrians. J.R. Perry, "New Persian." In Literacy in the Persianate World: Writing and the Social Order, ed. B. Spooner and W.L. Hanaway (Philadelphia: University of Pennsylvania Press, 2012): 70-94.

4 M. Kia, Persianate Selves: Memories of Place and Origin Before Nationalism (Redwood City: Stanford University Press, 2020).

5 For example, see S. Pollock, The Language of Gods in the World of Men: Sanskrit, Culture and Power in Premodern India. (Berkeley: University of California Press, 2006). For a note that the Sanskrit and Arabic 'cosmopoleis' overlapped in South and Southeast Asia, R. Ricci, Islam Translated: Literature, Conversion, and the Arabic Cosmopolis of South and Southeast Asia (Chicago: University of Chicago Press, 2011): 13-4. 
patterns, but each of the articles touches upon these matters within their respective contexts, both substantively and analytically.

Here in the introduction, we can only point towards some of these lines of thought. The first of these lines concerns the way in which the Persian language was used. If we define the Persianate based on the minimalist criterion of significant historic use of the language, regardless of whether or not other languages were also in use, and whatever the religious affiliations of such users, we would still have to confront the enormous variations in uses of the language. In the time period covered by this collection-the seventeenth to the early twentieth centuries $\mathrm{CE}$-Persian was spoken by the majority of people in the lands of what are today Iran, Tajikistan and Afghanistan - a relatively smaller area than all those other parts of the world in Southeast Asia, South Asia, Central Asia, Central Eurasia ${ }^{6}$ and Anatolia where people used the language to write in, without speaking it very often or at all. Led by Jack Goody's seminal work on the distinctiveness of writing as a cultural endeavour, and the sociological as well as cognitive implications of such, ${ }^{7}$ scholars have called for specific attention to the phenomenon of Persographia, which is to say, writing in Persian, as opposed to Persophonie or speaking in Persian. ${ }^{8}$ Unlike Goody and the anthropologists who worked in his wake, the impetus in this case is not to distinguish between societies of oral communication and those that used writing, but to trace the variable use of Persian between the ninth and nineteenth centuries across a range of social and spatial loci, and its co-location and interaction with other written languages as well as its situation within speech communities. Of these variations, we may note some of the societies that used Persian writing for spiritual-literary or genealogical-memorial uses, as for example in Bosnia or Southeast Asia, did not use it for administrative, fiscal or commercial record-keeping;'9 in the Indian subcontinent it was used for the whole range of uses but in regionally variable combinations with other written (and spoken) languages. The complexity of this variation, as well as

6 The neglected 'northern circuit' of transmission focussed on Central Asia, and comprising of Inner Russia, Siberia, the Qazaq Steppe, the Tarim Basin and the Northern Caucasus. D. DeWeese, "Persian and Turkic: From Kazan to Tobolsk." In The Persianate World, ed. Green: 131-56.

7 Jack Goody and I.P. Watt, "The Consequences of Literacy." Comparative Studies in Society and History 5 (1963): 304-45; developed in several later works.

8 B. Spooner and W.L. Hanaway, "Introduction." In Literacy in the Persianate World, ed. Spooner and Hanaway: 27-59; Green, "Introduction." In The Persianate World: 5-8.

9 H. Algar, "Persian Literature in Bosnia-Herzegovina." Journal of Islamic Studies 5/2 (1994): 25467; S.F. Ng, "The Alexander Romance in Southeast Asia: Wonder, Islam and Knowledge of the World." In Alexander the Great in the Middle Ages: Transcultural Perspectives, ed. M. Stock (Toronto: University of Toronto Press, 2016): 104-22. 
changes over time, has kept us from attempting to produce a map of variable Persographia even for the parts of the world that the papers collected here touch upon. It is sufficient to note here that the documentary artefacts studied by all articles in this collection (barring Fahad Bishara's) are products of Persographia, but not necessarily Persophonie.

Having restricted the scope of what we are about, it is now time to expand. The articles in this collection treat Persographia not just as the writing of Persian, but as Persianate writing, in the sense of writing within contexts that were evidently inflected by Persian. Thus, they deal with the writing of Persian words, phrases, even complete sentences in non-Arabic scripts and they deal with writing in languages (for example Marathi, Rajasthani, Bengali) that were laden with Persian loan-words and locally synthesized words and phrases. They also look along another geographical-linguistic axis and deal with the presence of Arabic, not simply as the original source of words and concepts received in Iran and India via Persian, but also as a contiguous and overlapping cultural zone. To indicate our thinking schematically, we are not thinking of language relations in terms of Arabic $\rightarrow$ Persian $\rightarrow$ Indic vernaculars, but actually Persian $\leftrightarrow$ Arabic as equivalent to (for example) Persian $\leftrightarrow$ Rajasthani. This means that, for the purposes of this collection, we are treating materials that are entirely in Arabic or Rajasthani as part of the story of the Persianate because they played demonstrably crucial roles in facilitating the working of the overall systems of trade, communication or governance in the Persianate world. By taking this radically inclusive approach to languages, we are doing three things. Firstly, and most obviously, we are thinking of the Persianate truly as a zone, and paying more even-handed importance to Persian and non-Persian cultural elements within it. Secondly, and more adventurously, we are attempting to de-fetishize language, and de-couple it from its usual pairing with literary genealogies. We are interested in what language does at any moment in time and space; besides frequent and fluent users of Persian, we also include those that use only bits of it, or not at all, in the story of the Persianate, because it is that totality that makes the 'multilingual local' function. ${ }^{10}$ Finally, the attention several of the articles pay to the presence of explicitly Islamic legal concepts and vocabulary, allows us to step beyond the idea of the Persianate as a suprareligious cultural zone and deal with Islam as a source of ideas and practices.

While most works on the Persianate insist on the need for understanding it as more than Iran-plus or Persian-plus, the Indian subcontinent, despite being a core sub-zone of the Persianate, continues to baffle researchers. 
This is because with its numbers - of languages, people and wealth-India dwarfed other parts of the Persianate world and cannot be plausibly tackled as a single sub-zone. Even the usage of Persian as prestige language varied significantly between the domains of the Mughals in northern India and those of the Sultanate and Maratha Deccan; for us this means different sorts of document forms, official lexicons and even calendars. In order to really understand the regionally-specific relations formed by cosmopolitan Persian with other developed vernacular languages in this demographically and culturally dense region, one needs linguistic competence beyond any single researcher. Moreover, many researchers with the necessary Indic-language skills and regional expertise (in Marathi or Rajasthani, for example) do not see their areas as part of the Persianate world. This special issue is the product of an unusual team of scholars who brought together their knowledge of Arabic, Bengali, Hindi, Gujarati, Marathi, Rajasthani, and of course-Persian. We also worked as a team, sharing our linguistic competences and our knowledge of sources, and in doing so we were able to substantiate the very pragmatic cultural translations that were involved in the production of the materials with which these articles are concerned.

Such an approach is essential because this collection aims to make a specific contribution to studies of the Persianate and Persographia through focus on a specific social register and body of materials. Studies of the Persianate writing (and listening) world have until recently concentrated on highbrow literary production including courtly chronicles, translations from other prestige languages, poetry, writings about poets and spiritual writings by and about Sufis. ${ }^{11}$ While valuable, such scholarship has the effect of producing a skewed view of language use; one that over-emphasises the cultural and intellectual achievements of the highly literate, casting the rest in the role of avid but largely passive listeners. ${ }^{12}$ It fails to capture the much wider terrain of language use, which includes pragmatic record-keeping and commercial dealing, by many whose knowledge of the Persian language was limited to memorized phrases, but for whom usage of such phrases was natural, functional and embedded within the lexicon and semantics of the other languages that they spoke or

11 This is true of the works cited above, as well as the Journal of Persianate Studies, published since 2008; on translations to Persian from Indic languages, see A. Truschke, Culture of Encounters: Sanskrit at the Mughal Court (New York: Columbia University Press, 2016) and the Perso-Indica project.

12 Creative research that incorporates practices of oral recitation into the studies of text does not overcome the focus on the highbrow. F. Orsini and K. Schofield, ed., Tellings and Texts: Music Literature and Performance in North India (Cambridge, UK: Open Book Publishers, 2015). 
wrote. To take a striking example of this methodological blind-spot, scholarship on the workings of the Mughal empire in India, especially work produced up until the 1980s, made extensive use of Persian and bi-lingual documents extant in various libraries and archives in India and Pakistan, but treated such materials as sources of political, social and economic data, and as emanations of the Mughal state apparatus. The cultural significance of such material was disregarded, as were the non-Persian elements in them. Studies of Persian language and 'Indo-Persian' culture, on the other hand, even by the same scholars, focused on texts of higher literary value - poetry, hagiographies, moral guides and such. ${ }^{13}$

As an aside, it is worth noting that, within these methodological parameters, seminal works by scholars such as Muzaffar Alam and of others from the 'Aligarh school' paved the way for a later generation of scholars who are more explicitly engaged with the processes of global circulation of Persian rather than its one-way transfer, and who no longer favour the term 'Indo-Persian.' The reason for that choice is the association of the label 'Indo-Persian' with the epithet sabk-i Hindī (Indian style), invented in the early twentieth century by emigré Iranian scholars nurtured in continental European philological traditions, whose 'metageographical' approach bemoaned the alleged degradation of Persian beyond its homeland. ${ }^{14}$ 'Persianate' is a scholarly choice by others keen to enquire into the dynamics of the deterritorialisation of Persian, unhindered by crypto-nationalistic linguistic and literary standards. It also signals an interest in the other languages that were in historically creative relationships with Persian; this is something that we are inspired by in this collection.

Since 2010, four themed journal issues have laid the foundations that we are attempting to build on here. The first is a section on 'Trade and traffic in the Persianate world,' which formed part of a larger themed issue of the Comparative Studies of South Asia, Africa and the Middle East on 'The Indo-Persianate world.' In introducing that section, the editors took the Persianate world as a historical fact, as well as a historiographical aspiration. They defined the analytical aim

13 The best example of this variation in use and interpretation of sources is M. Alam, Crisis of Empire in Mughal North India: Awadh and the Punjab, 1707-1748 (Oxford: Oxford University Press, 1986) and M. Alam, The Language of Political Islam: India, 1200-180o (London: Hurst \& Co., 2004).

14 R. Kinra, "Fresh Words for a Fresh World: Tāzā-Gü' and the Poetics of Newness in Early Modern Indo-Persian Poetry." Sikh Formations 3/2 (2007): 125-49. 
of the collection of essays thus: [to] 'break away from geographic frontiers ... to reveal the ties between Iran and the world beyond it. ${ }^{15}$ The rich collection, on Iranian, Central Asian and European merchants, travelers, their licit and illicit trade, and the technologies they used, was predominantly sociological in character, in line with the Braudelian paradigm the group set for itself.

The other two collections did not headline the 'Persianate' as a conceptual or empirical entity but are closer in spirit to this volume because of their focus on the kind of brief, determinate, functional writing that we may call 'documents.' They also worked on overlapping historical-cultural zones which included large chunks of the Persianate world. The Journal of the Economic and Social History of the Orient's special issue in 2019 on 'Islamic Cultures of Documentation' consisted of a well-coordinated set of essays dealing with the production, circulation and storage of such documents from India, Iran and Central Asia and the Ottoman Empire, in a planned effort to engage with and problematize the notion of the archive across a range of contexts: Islamic, Persianate, and 'Indo-Persianate.'16

Also in 2019, Modern Asian Studies hosted a special issue on 'Petitioning and Political Cultures in South Asia,' which dealt with a range of documentary forms in several South Asian languages, including Persian, with which the people of the region have historically tried to address the state and express their expectation of it. Because the burden of this collection was to study political culture together with state-formation through a range of documentary genres, it took a relatively light touch in its attention to form. Taking an 'open-ended view of what constitutes ... a petition,' authors discussed 'forms of address to political authority' from various parts and periods of the South Asian past. ${ }^{17}$ The imperative was to study a specific axis of state-society dialogue that facilitated state building and disciplining on the one hand, and political agency on the other. Incidentally, as it were, several essays in this volume had much to say about the culture of writing documents in Persian.

In 2016, a fourth collection took a broader approach, and attempted to investigate the Persianate as a temporally specific phenomenon. The four essays in 'After the Persianate' usefully refined our understand of when and how the Persianate world ended, coming to the conclusion that it was much later than

15 P. Mahdavi and A. Khazeni, "Trade and Traffic in the Persianate World." Comparative Studies of South Asia, Africa and the Middle East 30/3 (2010): 398.

16 J. Pickett and P. Sartori, "From the Archetypical Archive to Cultures of Documentation." Journal of the Economic and Social History of the Orient 62/5-6 (2019): 773-98, and other essays in that volume.

17 R. De and R. Travers, "Petitioning and Political Cultures in South Asia: Introduction." Modern Asian Studies 53/1 (2019): 6. 
previously believed: well into the twentieth century, when technologies of travel, print and even nationalisms facilitated the growth of new forms of cosmopolitan sociability in the same cultural zone. ${ }^{18}$

Our present collection, then, draws on the aims of all four of these collective scholarly efforts. We are concerned with the cultural implications of the Persianate, as well as its conceptual fuzziness, and attempt to describe some of its previously neglected features while delineating its limits in time and in space. To focus our contribution, the papers collected here are specifically about business, and about the business of writing. We are acutely aware that the world of global commerce, which began to take modern shape from the sixteenth century, spread on the backs of non-European capital, as well as through the fissures of non-European political regimes. ${ }^{19}$ Most importantly for us, this business was transacted by a host of protagonists throughout the age of empires, and in languages and jargons that were overwhelmingly nonEuropean. And yet, all those contracts, letters, receipts and other commercial paraphernalia remain invisible in a historiography that tells us about indigenous merchants, but neither in their own words nor with reference to their own technologies. Instead, generations of economic historians have traced non-western entrepreneurship through the archives of European trading companies and colonial governments, only anecdotally supplemented with some contextual details from courtly chronicles or travel accounts in Arabic, Persian and Indic languages. ${ }^{20}$ But it is simply not the case that Europeans had records

18 See introduction and essays by Mana Kia, Afshin Marashi, Tallinn Grigor, Alexander Jabbari and Farzin Vejdani in Comparative Studies of South Asia, Africa and the Middle East 36/3 (2016): 379-454.

19 C.A. Bayly, Rulers, Townsmen, and Bazaars: North Indian Society in the Age of British Expansion, 1770-1870 (New York: Cambridge University Press, 1988); K.N. Chaudhuri, The Trading World of Asia and the East India Company, 1660-1760 (Cambridge: Cambridge University Press, 1978); O. Prakash, "The Indian Maritime Merchant, 1500-180o." Journal of the Economic and Social History of the Orient 47/3 (2004): 435-57; B. Raman, Document Raj: Writing and Scribes in Early Colonial South Asia (Chicago: University of Chicago Press, 2012); R.K. Ray, "Asian Capital in the Age of European Domination: The Rise of the Bazaar, 180o-1914." Modern Asian Studies 29/3 (1995): 449-554; L. Subramanian, "Banias and the British: The Role of Indigenous Credit in the Process of Imperial Expansion in Western India in the Second Half of the Eighteenth Century." Modern Asian Studies 21/3 (1987): 473-510.

20 This is true of K.N. Chaudhuri, A. Das Gupta, and even G. Nadri, who has taken a different approach in this volume. K.N. Chaudhuri, Trade and Civilisation in the Indian Ocean (Cambridge: Cambridge University Press, 1985); A. Das Gupta, Indian Merchants and the Decline of Surat, 1700-1750 (Wiesbaden: Steiner, 1979); G. Nadri, Eighteenth Century Gujarat: The Dynamics of its Political Economy (Leiden: Brill, 20o9). The perhaps sole exception to this methodology is S.D. Aslanian, From the Indian Ocean to the Mediterranean: The 
and non-Europeans only had tales. This volume draws attention to the vast volume of Persianate documentation in the bazaar and looks out from that vernacular marketplace into the broader arena of law, commerce and empire.

Persian documents often evoke visions of gold-sprinkled orders and letters usually written by or for emperors. In line with our collective effort to deepen and enrich our understanding of the Persianate world, the articles in this volume step beyond royal courts and literary assemblies into the domain of transactions. In this volume, we are concerned with documents produced to record a range of transactions in India, Iran and the Indian Ocean between the seventeenth and nineteenth centuries. Protagonists of these articles include, among others, Qajar noblewomen, Maharashtrian brahmin scribes, Rajasthani Sufi pirs, Gujarati bania revenue farmers, African mariners and British officials. They take loans, claim personal freedom, hide tax information and squabble over inheritance; some worry about Islamic injunctions against usury, and others don't. Such transactions, and the socio-geographic spaces they were enacted in, demonstrate that the economic processes of the market were inseparable from the household or the state. Some of these transactions were explicitly commercial, while others involved a range of contractual and legal devices, credit-transfer practices, fiscal and even political entrepreneurship. As such, the totality of such transactions is better encompassed by the Persian loan word in English - 'bazaar' - with its connotation of personal relationships, rather than the impersonal, almost magical forces of the self-regulating 'market.' In this sense, our bazaar with its economically relevant social relationships is similar to the usage of that term by C.A. Bayly ${ }^{21}$ and also Clifford Geertz. Insofar as Geertz used the term to explicitly address the features of North African markets, the Arabic souk is included within the notion of the bazaar. ${ }^{22}$

Of course, the bazaar comes with its own baggage of pejorative associationsthat of small-scale 'petty' trade, peddled by Asian (or Arab) merchants, always constrained by market fragmentation, information bottlenecks and lack of institutional mechanisms, and by their own religio-cultural irrationalities, propensity for hoarding and various uneconomic barriers to productive investment. Such peddlers may have survived and slunk through the cracks of European capitalism, and in doing so they inhabited the poorer, backward-looking side of the dual economy created in regions of the world dominated by European

Global Networks of Armenian Merchants from New Julfa (Berkeley: University of California Press, 2011).

21 Bayly, Rulers, Townsmen and Bazaars.

22 C. Geertz, "The Bazaar Economy: Information and Search in Peasant Marketing." The American Economic Review 68/2 (1978): 28-32. 
capital. Since the 1980s, however, historians such as Rajat Ray have drawn attention to the vast international networks of Asian capitalism, which, in relying on kinship and community relations, were no less productive, enterprising or ambitious. ${ }^{23}$

The bazaar we are talking about in this collection is that 'broader site of finance, of contracting, and of conversion - of capitalism more broadly.' ${ }^{24}$ Like its better-known sibling, 'market,' it is not just a descriptive but a conceptual category that holds within it the forms, institutions, ideas, and practices that give exchange its history. ${ }^{25}$ It allows historians to move away from the discussions of imperially-centred political economy that have long dominated the literature on the economic history of the non-Western world. ${ }^{26}$ Just as the Persianate allows us to conceptualise a trans-polity zone, so does the bazaar. With its focus on connection and circulation, the bazaar crosses imperial borders, traverses the city and the countryside and stretches from the land to the sea. And pertinently for this collection, we propose that in the documentary architecture of the bazaar we see the conceptual, and particularly the legal frameworks that animated the marketplace: the notions of property, wealth, rights, and contract that we have long known to have underpinned the history of capitalism in Europe and the Atlantic world, but which so often are missing from accounts of exchange in the Islamic and Persianate worlds. Economic exchange in the partially overlapping Islamic and Persianate worlds was certainly not separate from cultural and intellectual exchange: jurists, qazis, traders, and officials constantly grappled with the contracts and concepts that gave economic life its shape, and, through various means, sought to regulate them.

23 Ray, "Asian Capital"; in a similar but not quite as polemical vein, see C. Markovits, The Global World of Indian Merchants, 1750-1947 (Cambridge: Cambridge University Press, 2000).

24 F. Bishara, "The Diver's New Papers" in this double theme issue.

25 The literature on markets and institutions in economics and sociology is enormous. For illustrative examples, see D. North, Institutions, Institutional Change, and Economic Performance (Cambridge, UK: Cambridge University Press, 1990); N. Fligstein, The Architecture of Markets: An Economic Sociology of Twenty-First Century Capitalist Societies (Princeton: Princeton University Press, 2001), 27-98. For a useful historical perspective on these questions, see also K. Lipartito, "Reassembling the Economic: New Departures in Historical Materialism." American Historical Review 121/1 (2016): 101-39.

26 Some outstanding examples include T. Kuran, The Long Divergence: How Islamic Law Held Back the Middle East (Princeton: Princeton University Press, 2011), where the focus is on the Ottoman Empire; P. Parthasarathi, Why Europe Grew Rich and Asia Did Not: Global Economic Divergence, 1600-1850 (Cambridge: Cambridge University Press, 2011) which focuses on the Mughal and British empires, with a nod to the Ottomans; Sven Beckert, Empire of Cotton: A Global History (New York: Vintage Books, 2015). 


\section{Forms of Law across the Spaces of Persianate Multilingualism}

But if thinking from the bazaar allows us to see how legal practice is bound up in a commercial world and vice versa, it also challenges us to think more closely about the contours of what makes up law in the bazaar. The literature on Islamic law is now enormously rich and varied, aware of its continued vitality over centuries and its doctrinal diversity as well as rigour. ${ }^{27}$ With scholars working on a range of source materials, it now accommodates scholarship on everyday practices of law as much as traditional investigation into jurisprudence. ${ }^{28}$ That scholarship pushes us to think about the varied sources of law-beyond jurisprudence and collations of learned responses to administrative manuals, market practices and 'custom' in its widest range of senses-including market practices. The bazaar thus appears to us not just as an arena of law produced elsewhere; it is generative of law itself. ${ }^{29}$ It appears to us as a world in which commercial and legal lexicons bleed into one another, in which actors thread their documents through many different legal institutions, producing instantiations of 'law' not always captured in works of learned jurisprudence.

We are not satisfied with the picture of a custom-tempered world of Islamic law merely tolerated by European capital and surviving under the radar of European empires. In several articles in this collection, the English East India Company and British colonial agencies make multiple appearances, actively participating in the bazaar world and its documentation practices, providing a certificate of freedom (barwa) here and dealing with a blood-money claim (as compensation for manslaughter) there. As Fahad Bishara and Hollian Wint have proposed, 'Euro-American capitalism's very agents had to adapt

27 Wael Hallaq's enormous corpus being transformative in this respect. W. Hallaq, Sharĩa: Theory, Practice, Transformations (Cambridge: Cambridge University, 2009).

28 The literature is too large to summarise here; but for works dealing with 'everyday practice' that have inspired us, see: J. Baldwin, Islamic Law and Empire in Ottoman Cairo (Edinburgh: Edinburgh University Press, 2016); P. Sartori, Visions of Justice: Sharīa and Cultural Change in Russian Central Asia (Leiden: Brill, 2016). We have offered our own efforts in F. Bishara, A Sea of Debt and N. Chatterjee, Negotiating Mughal Law: A Family of Landlords across Three Indian Empires (Cambridge: Cambridge University Press, 2020).

29 Works that inspire us include A. Udovitch, "Islamic Law and the Social Context of Exchange in the Medieval Middle East." History and Anthropology $1 / 2$ (1985):445-65, which looked at books of jurisprudence with a Geertzian lens; A. Udovitch, "Bankers without Banks: Commerce, Banking, and Society in the Islamic World of the Middle Ages." In The Dawn of Modern Banking (New Haven: Yale University Press, 1979): 255-73; M. O'Sullivan, "Paper Currency, Banking, and Islamic Monetary Debates in Late Ottoman and Early Saudi Arabia." Journal of the Economic and Social History of the Orient 63/3 (2020): 243-85; M. O'Sullivan, "Interest, Usury, and the Transition from 'Muslim' Banks to 'Islamic' Banks." International Journal of Middle Eastern Studies 52/2 (2020): 261-87. 
their commerce to the idioms, logics, and contracts of their business partners around the Indian Ocean - a vernacular world of the bazaar that was itself already in motion.' ${ }^{30}$ The documents thus produced, written in Persian, Arabic and Indic languages, are sometimes widely recognisable Islamic legal forms; in other cases, they are specific imperial forms, whether Mughal or British.

In the regionally and temporally specific forms studied by these articles, we see vocabulary derived as much from Islamic legal texts as from Mughal or Bijapuri fiscal governance, Qajar bazaar practice or indeed British imperial institutions. Awareness of this lexical variety does not just signal conceptual creativity and institutional crossings, it also reveals the internal borders of the Persianate. To take two examples, the flexible forms of contracts popular in Qajar Iran failed to catch on elsewhere, while blood-money claims remained recognisable in all areas covered by this volume. And all the time, Arabic-speaking and Arabic-writing communities brushed alongside the Persian writers; among users of Arabic we find maritime labourers and merchants sweeping the Indian Ocean from Gujarat to Bushire and from Bahrain to Zanzibar. ${ }^{31}$ We are not clear to what extent this preference for writing documents in Arabic was determined by socio-economic class; geographically, the Perso-Arabic Gulf appears to have provided a space of linguistic (graphic) transition, west and southwest of which we have little use of Persian and Arabic takes over its cosmopolitan functions. ${ }^{32}$

Which brings us to the other spatial hermeneutic that we were constantly aware of while producing the papers assembled here-the Indian Ocean. The cool kid of maritime history, bearing the heavy imprint of the Braudelian Mediterranean, work on the Indian Ocean has until recently been dominated by an emphasis on trade and empire. ${ }^{33}$ While informed by those older works, we are most immediately inspired by works produced since the 20oos which have attempted to peel back the mythical veil of the impersonal market and

$30 \quad$ F. Bishara and H. Wint, "Into the Bazaar: Indian Ocean Vernaculars in the Age of Global Capitalism." Journal of Global History 16/1 (2021): 44-64.

31 R.J. Barendse, Arabian Seas, 1700-1763 (Leiden: Brill, 2009); S. Bose, A Hundred Horizons: The Indian Ocean in the Age of Global Empires (Cambridge, MA: Harvard University Press, 2006): 72-121; Ray, "Asian Capital"; A. Villiers, "Some Aspects of the Arab Dhow Trade." Middle East Journal 2/4 (1948): 399-416; A. Villiers, Sons of Sinbad (New York: Charles Scribner's Sons, 1949).

32 J. Onley, "Transnational Merchants in the Nineteenth Century Gulf: The Case of the Safar Family." In Transnational Connections and the Arab Gulf, ed. Madawi al-Rasheed (London: Routledge, 2004): 59-89.

33 K.N. Chaudhri, Trade and Civilisation in the Indian Ocean: An Economic History from the Rise of Islam to $175^{\circ}$ (Cambridge: Cambridge University Press, 1985). 
reveal the legal and cultural-institutional processes that underlay trade in these aqueous circuits and their hinterlands. ${ }^{34}$ We were also inspired by powerful interventions in which the Indian Ocean is depicted as a capacious, open-ended domain, crisscrossed by many circuits, productive of historical universalisms, and historiographic possibilities of 'de-segregated', or 'disaggregated,' and reassembled writing. ${ }^{35}$

Specifically with relation to our collective aims, we felt that engaging with the Indian Ocean and its history would allow us to explicitly evaluate the adjectives Islamicate and Persianate (and Indic) and explore where exactly those overlapped and separated. This proved very difficult to do and to some extent we were hampered by trends in existing scholarship. For one thing, there is the matter of language: the Indian Ocean is seen to form part of the Arabic cosmopolis, ${ }^{36}$ comfortably admitting the Indic, but rarely overlapping with Persianate Eurasia. When scholars work on Persianate Gujarat, Bombay or Bengal, all on the Indian Ocean rim, their attention turns landwards, rather than seawards. ${ }^{37}$ Conversely, when the Indian Ocean is the quantity under study, Persian language, even if present and acknowledged, is treated as an incidental presence, not as the core of a cultural circuit in its own right. ${ }^{38}$ Then there is also the relative emphasis on trade. The Indian Ocean is readily seen as the domain of monsoons and merchants, and in later periods that of students, lawyers and nationalists. But when there are studies of commerce within areas we would recognize as 'Persianate,' very few of those scholars ${ }^{39}$

34 P. Risso, Merchants of Faith: Muslim Commerce and Culture in the Indian Ocean (Curzon: Routledge, 2018); S.R. Prange, Monsoon Islam: Trade and Commerce in the Indian Ocean (New York: Columbia University Press, 2018); F. Bishara, A Sea of Debt: Law and Economic Life in the Western Indian Ocean, 1780-1950 (Cambridge: Cambridge University Press, 2017); G. Sood, India and the Islamic Heartlands: An Eighteenth-Century World of Circulation and Exchange (Cambridge: Cambridge University Press, 2016); S. Aslanian, From the Indian Ocean to the Mediterranean.

35 Isabel Hofmeyr, "The Complicating Sea: The Indian Ocean as Method." Comparative Studies of South Asia, Africa, and the Middle East 32/3 (2012): 584-9o.

36 Ricci, Islam Translated; the point is explicitly made in Green, "Introduction": 28-9.

37 This is true even when scholars of the Persianate work on areas on the Indian Ocean rim. T. d'Hubert, In the Shade of the Golden Palace: Ālāol and Middle Bengali Poetics in Arakan (New York: Oxford University Press, 2018).

38 See Sood, India and the Islamic Heartlands: S. Subrahmanyam, "Of Imarat and Tijarat: Asian Merchants and State Power in the Western Indian Ocean, 1400-1750." Comparative Studies in Society and History 37/4 (1995): 750-80.

39 S. Subrahmanyam, "Persianization' and 'Mercantilism' in Bay of Bengal History, 1400170o." In Explorations in Connected History: From the Tagus to the Ganges (Oxford: Oxford University Press, 2005): 45-79. 
actually engage with the phenomenon of the Persianate as such. ${ }^{40}$ Even Nile Green, in his exciting proposal for re-conceptualising the 'Middle East' using an 'interaction-based arena model' similar to the Islamicate Mediterranean, ${ }^{41}$ separates the Persianate 'Inner Asia Arena' from the 'Indian Ocean Arena.' The Persianate and the Indian Ocean Worlds are hard to bring to the same party.

With the papers assembled in this collection, we took some small steps towards joining those wires by placing our fulcrum in South Asia, where these two great circuits of the Islamic world met. In doing so, we see, unsurprisingly and in line with the works cited in the previous paragraph, that Persianate folks were able to not just recite poetry and contemplate spiritual or political grandeur, but also crunch numbers and clinch deals. What is more useful, perhaps, is that we found that the ways in which they went about recording that business overlapped sufficiently with the Arabic-writing people around the Indian Ocean for economic actors to move between different languages and registers of contracting - to say nothing of contractual forms - with remarkable facility. ${ }^{42}$

We note that that this collection also takes issue with the primarily suprareligious view of the Persianate. If we take 'religion' in its capacious meaning, beyond the Protestant conceptualisation as 'faith,' we can begin to acknowledge the vast international role of Islamic law, as a source of concepts, practices and forms, and indeed, as a vital axis connecting the Persianate with the Arabic cosmopolis on the one hand and the Sanskrit/Indic cosmopolis on the other. Several articles in this collection deal with documentary forms that would be recognized throughout the Islamic world. One such documentary form was the iqrār. Legally binding declarations treated as the best kind of evidence by Islamic jurists, iqrārs abound in collections around the Islamic world,

Silk Road studies are a field in their own right; works that specifically refer to recognisably Persianate circuits are C. Markovits, The Global World of Indian Merchants, 1750-1947 (Cambridge: Cambridge University Press, 200o); S. Levi, The Indian Diaspora in Central Asia and its Trade, 1550-1900 (Leiden: Brill, 2002). An exception to this formulation is A. Khazeni, "Merchants to the Golden City: The Persian Farmān of King Chandrawizaya Raja and the Elephant and Ivory Trade in the Indian Ocean." Iranian Studies: Bulletin of the Society for Iranian Cultural and Social Studies 51/6 (2018): 933-45. There is considerable notice taken of in-bound horse trade from Central Asia and the Persian Gulf, and the horse-trading ancestry of several South Asian rulers and king-makers, but the trade itself is studied as an adjunct to war and empire-building in J.J.L. Gommans, The Rise of the Indo-Afghan Empire, c. 1710-1780 (Leiden: Brill, 1995); Flatt, Courts of the Deccan Sultanates: $120-64$.

$41 \quad$ N. Green, "Rethinking the "Middle East" after the Oceanic Turn." Comparative Studies of South Asia, Africa and the Middle East 34/3 (2014): 556-64. 
predominantly as record of monetary debts in Arabic-writing contexts. They appear in many of the articles in this volume too, but in these they are shown to perform a wider variety of functions, from recording inter-personal contracts to inter-polity treaties. The legal fictions of Shici Iran, Arabic colloquialisms along the East African coast and Indic mercantile practice intertwine, pushing us to think seriously about the Persianate as more than just hegemonic Persian, but really about 'interlinguistic contact.' 43

This is also a study of cosmopolitanism, specifically with Persianate multilingualism as its historical locus. We are fully aware that cosmopolitan spaces do not erase difference; documents reveal, in fact, the regional and even trans-regional efficacy of culturally specific forms (for example the Indic bill of exchange, or hundī). In studying the precise functions of the culturally specific, we are able to look past anachronistic ethno-nationalisms which see vernacular developments as necessarily oppositional. ${ }^{44}$ This does not mean that we see the Persianate world as one of free flow. Trans-cultural communication obviously requires access to sufficient cultural resources, but this was not necessarily just an elite privilege; unlike those who work on the highbrow Persianate, we are able to trace such communication in functional exchanges, not just in the realm of courtliness or $a d a b .{ }^{45}$ Recent scholarship is moving to explore how multi-lingual terrains operate; ${ }^{46}$ our un-literary legal documents are a fecund, if not pretty, place to investigate the same question. For here we have a swirling stream of languages including-besides explicit and full bilingualism-plurilingual practice where users demonstrate uneven facility in the different languages they use; we even have sound playing an important role as individually or collectively misheard words are transmitted, bearing

43 Green, "Introduction": 23.

44 For an argument on the 'proto-nationalism' of the Maratha state, see C.A. Bayly, The Origins of Nationality in South Asia: Patriotism and Ethical Government in the Making of Modern India (Oxford: Oxford University Press, 2001); for closer studies of Perso-Marathi bilingualism and the question of vernacularisation, see S. Guha, "Mārḡ̄, Deśı́ and Yāvanī: High Language and Ethnic Speech in Maharashtra." In Mārga: Ways of Liberation, Empowerment, and Social Change in Maharashtra, ed. M. Naito, I. Shima, and H. Kotani (New Delhi: Manohar, 2008), 129-46; R. Eaton, "The Rise of Written Vernaculars: The Deccan, 1450-1650." In After Timur Left: Culture and Circulation in Fifteenth-Century North India, ed. F. Orsini and S. Sheikh (Oxford: Oxford University Press, 2015), 112-29.

45 M. Kia, "Space, Sociality and Sources of Pleasure: A Response to Sanjay Subrahmanyam." Journal of the Economic and Social History of the Orient 61/1-2 (2018): 256-76.

46 W. Hakala, Negotiating Languages: Urdu, Hindi and the Definition of Modern South Asia (New York: Columbia University Press, 2016); F. Orsini, "How to do multilingual literary history? Lessons from fifteenth- and sixteenth-century north India." The Indian Economic and Social History Review 49/2 (2012): 225-46; several of the articles in Orsini and Schofield, Tellings and Texts. 
some part of the old meanings, and adding more. Additionally, we have the opportunity to examine contexts with historically significant anti-Persian indigenisms, for example in the Marathi case, and the finding is that despite the ideological posturing by regimes, everyday practice remained imbued with Persian. ${ }^{47}$

Several of the papers in this collection address the process of the protracted end of the Persianate. And we do believe it ended; despite the welcome pushing back of the end date by revisionist historians. The process was curiously Janus-faced. Some of the papers are explorations of new forms of that cosmopolitan dispensation that arose from the eighteenth century and persisted well into the twentieth. Other papers tell stories of exclusion. These include cultural-political indigenisms - that is, ideological and to some extent substantive resistance to the cosmopolitan, whether that be rejection of supposedly degenerate forms of Persian beyond Iran, or of Persian itself (in parts of South Asia). They also include statist moves - for example in Pahlavi Iran - to create expansive extra-territorial citizenships laws that filtered out the now invalidated participants of the older multi-ethnic order.

It is our aspiration that this effort at studying the documentary history of transactions will open up a substantive and as-yet unexplored axis with which to contribute to the fields of Persianate studies, Islamic economic history and the histories of imperial legal cultures. Such an approach has the merit of directly addressing matters of institutional and state power, and the sociological ones of situationally effective communication, as well as the broader issue of cultural formation. And at its broadest, we hope that our effort will serve to uncover the culturally intricate bazaar that underlay the seemingly flattening world of global capitalism.

\section{Scope and Foci of the Collection}

The articles in this collection deal with contexts from the mid-seventeenth century until the early twentieth, and from Chittagong to Zanzibar. The principal sites mentioned in the articles are plotted on a map that also indicates, roughly, of course, the broad zones of language use.

Maps of language zones are necessarily imprecise, because language use does not abruptly terminate at a given longitude and latitude. There were also differences in the nature of usage-Persian use in South Asia was more written than spoken, for example - which have been discussed earlier in this essay but 


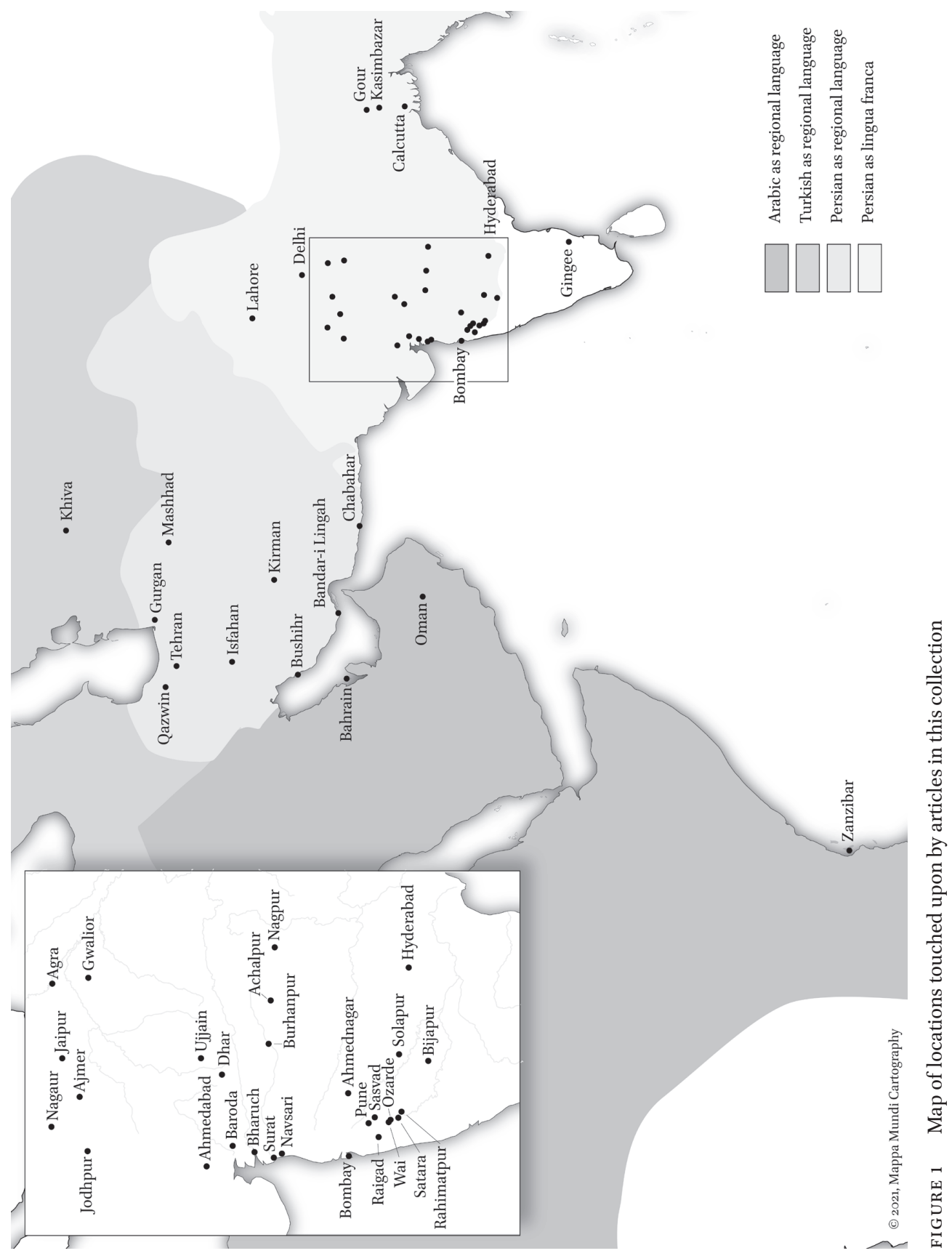


are not represented on this map in order to avoid visual clutter. Additionally, the map does not represent the geographical distribution of two major cosmopolitan languages relevant to the period covered by our articles-Sanskrit and English — nor any of the major regional languages of South Asia-Bengali, Gujarati, Hindi, Marathi, Rajasthani-which feature prominently in the articles. Once again, we have prioritized clarity over comprehensiveness in this visual tool. The purpose of the map is to offer a broad awareness of the Persianate world, together with information about the provenance of specific clusters of Persian documents and loci of Persianate writing mentioned in the articles. Once again, it is not the aim of the collection, nor of this map, to offer a comprehensive survey of surviving 'business documents' in Persian. If many of the locations are clustered in South Asia, this is partly due to the coverage offered by the articles. It is worth noting, however, that three out of the eleven articles deal with Iran, and one with the Indian Ocean. To some extent, the clustering of relevant locations in the Indian subcontinent also represents the historical density of people and urban locations in South Asia, not to mention the density as well as distribution of surviving Persian-language materials in this part of the world.

Besides geography, the articles can also be grouped in terms of their sociological context. Two of them deal with documents produced and used by full-time merchants. Mohammad Shahnawaz's article, on eighteenth-century registers maintained by Jain merchants at a mercantile centre called Sanganer in Rajasthan, north-west India, highlights the crucial role of the iconic Indian financial instrument, the hundī. Written in a cursive form of Rajasthani, these registers tracked the daily rates of discounting (i.e. 'cashing') hundīs issued in various locations across the Indian subcontinent. These registers are a wonderful source for the tracking of prices of credit across a large swathe of the Indian subcontinent in the eighteenth century. Attestations by merchant representatives and state officials on the margins of these registers and references in Persian and Rajasthani-language correspondence pertaining to the Rajput princely state of Amber also demonstrate a deep and sustained interest of such post-Mughal regimes in the workings of the market, and in the flow of credit in particular. A similarly multi-lingual context is evinced by the 1821 Persian-language document of representation or letter of attorney (wakalat nāma) discussed by Ghulam Nadri. Here, a substantial Parsi (Zoroastrian) merchant of Surat used a traditional Islamic legal form to appoint a representative for commercial litigation in the English East India Company's court in Surat. The witness notes in Gujarati, the reference to the Company's authority and the seal of the mufti or juriconsult of Surat point to the persistence 
of the Persianate and the Islamic within the emerging colonial legal system and the re-globalized Indian Ocean marketplace.

The papers on conditional, revocable sales and fictive reconciliation documents from Qajar Iran, by Nobuaki Kondo and Christoph Werner respectively, point to the crucial role of legal fiction in helping commercial actors, full-time merchants and others, to negotiate the tricky path between Islamic norms - for instance, the condemnation of usury — and their own economic goals. Kondo's paper on the use of bay $-i$ shart, or conditional sales, achieves two important tasks for the collection. First, by situating his formal and doctrinal exposé of such loan-deeds-posing-as-sale-deeds within several series of sharīa court records from nineteenth-century Iran, he demonstrates the methodology of relating document to doctrine to courts. Secondly, by situating the specifically Shi $i$ forms of such deeds in a wider Islamic context, including the work by Fahad Bishara of khiyār sale deeds from the Gulf and East Africa, ${ }^{48}$ this paper points to the fuzzy overlap between the Islamicate and the Persianate. This latter point is also raised by Werner's study of the popularity of șulh/mușālaha contracts in nineteenth and twentieth-century Iran. Although mușālaḥa in Islamic law indicated a settlement following a dispute, in Qajar Iran this contractual form was actually deployed for all kinds of transactions, especially those involving property transactions. Moreover, this particular legal fiction seems to have not caught on in contiguous parts of the Persianate world such as India or Central Asia- a point that alerts us to the uneven terrain of the Persian cosmopolis.

At the other hand of the scale, as far as translations are concerned, are articles about seemingly endless mutations of Islamic and Persian legal terms and forms via multiple Indic languages, cultural zones and regimes. Prachi Deshpande's paper takes us to the royal end of the spectrum of documents, presenting the kaulnāma, popular in the Marathi-writing zone of south-western India from at least the sixteenth century. This document's name displayed a joint Arabo-Persian etymology ( $q a w l=\mathrm{A}$. word/utterance; $n \bar{a} m \bar{a}=\mathrm{P}$. deed/letter), indigenized phonetically and orthographically in Marathi. The document served to record words of assurance from royal authority, creating deeds of entitlement of various kinds. What is striking about such generally bilingual 
(Persian-Marathi) royal grants was their persistent efficacy across regimes of the region from the sixteenth until the nineteenth centuries (Bijapur Sultanate, Mughal, Maratha, British colonial) regardless of the regime's sociological basis or ideological foundations. Deshpande's work points to overlaps in legal and documentary practice from the Arabo-Islamic Indian Ocean to the Persianate, land-locked parts of the Indian peninsula; it also indicates the continuities between pre-colonial and colonial documentation regimes, with cowlenamas serving as diplomatic treaties and cowls/cowles as land-lease deeds well into the nineteenth century.

Nandini Chatterjee's article looks at another such documentary chameleon, from a different, humbler social level and register. Chatterjee points to the appearance and uses of a paired set of Persian or bi-lingual documentary forms - the deed of obligation or tamassuk and the deed of release or färigh-khațtí-in political and judicial dispensations from the Mughal to postMughal to colonial. Using documents, manuals and literary sources, the article traces the repeated re-homing of these documentary forms across language zones-Persian, Urdu, Marathi, Bengali-and their deployment across a range of transactions, from the commercial to the fiscal. Chatterjee's article focusses on the interactions between legal and linguistic translation and argues that South Asian legal mentalités remained both Persianate and Islamic well into the twentieth century.

Fahad Bishara's article, situated in the world of Indian Ocean mariners of the twentieth century, discusses another kind of debt certificate or deed of obligation called the barwa. These tiny, matchbox-sized documents, written in simple Arabic, recorded (like the older Persian tamassuks), the amounts owed by subaltern mariners to various ship captains. But unlike the tamassuks, they also included stipulations directed at any potential employer of such indebted mariners, stating that the new employer had to pay off the amounts due to the old employer/creditor. Thus these tiny documents functioned as potent devices linking the market for 'micro-credit' with the market for maritime labour; tying the pearl divers and ship-hands to the ship captains in protracted economic transactions and relations of dependence. In showing how Arabo-Persian Gulf extensions of the Raj were sucked into this maritime paper economy, Bishara's article offers the complementary story of business writing in Arabic, connected by trade, geography and governance to the colonial Persianate.

Another paper that looks at inter-linguistic, inter-regime and intertransactional-zone usage is Dominic Vendell's essay on karārnāmā, popular in the Maratha empire of the eighteenth century, including in its dealings with the English East India Company. Forming a species of political contract, with its two columns of clauses individually ratified by the parties, the karārnāma served regimes as treaties and individual political players as 
business deals, powerfully wrenching open the gates between business and politics. Comparable to inter-polity ' $h d$-nāmas — in evidence in India as well as the Ottoman-Mediterranean world — but novel in its capacious Marathi/Maratha avatar where it helped conduct the actual 'business of politics' with monetary implications, the karārnāmā bears testimony to the constant fecundity of Persianate political, legal and documentary cultures.

Samira Sheikh's article, on multi-lingual revenue records from late eighteenthto early nineteenth-century Gujarat examines that lexical and formal fecundity in all its excess. Like Vendell's article, it also blurs the line between business and statecraft, this time via powerful bania family firms that acted as tax collectors for the small Muslim state of Bharuch in southern Gujarat. The process of conquest by the British entailed extracting information from these lineages that acted as profit-making corporations on the one hand and as agents of the state on the other, deciphering the dense and linguistically eclectic revenue terminology in which they dealt, and ultimately, displacing them. By giving the reader a story of such commercial-administrative actors together with a taste of the materials they dealt in, Sheikh presents us with a methodology of working through colonial records with multi-lingual competence in order to reconstruct phonetically, etymologically and normatively the multiform and multilingual practices of business and governance in Persianate South Asia. She also indicates how vernacular languages - in this case Gujarati-served as tools of colonial governance, in creating more uniform, regionally bounded and legible forms of governance, removing the impenetrable expertise of Persianate merchant-governors.

Elizabeth Thelen's article pushes past yet another commonly accepted distinction, that between the market, the sphere of transactions, and the family, the domain of emotions, kinship and non-transactional relationships. With virtuoso archival research, she connects Persian-language deeds preserved by a branch of a spiritually eminent lineage in partial charge of a major Sufi shrine in Rajasthan, with records in registers of legal disputes heard and resolved by judicial authorities in the Rajput kingdom of Jodhpur. In doing so, she not only opens up the social networks and property transactions that constituted the everyday life of a Muslim shrine in South Asia, but also connects scholarship on lineages and family with that on Sufi centres. In connecting Persian-language deeds with Rajasthani-language state records, her article makes a pioneering contribution to understanding the legal structures of post-Mughal successor states, besides making a striking point about the vibrant multi-linguality of Persianate South Asia, and of the participants in that language economy.

H. Lyman Stebbins' article closes this collection by bookending it geographically as well as temporally. The article explores the practices of extraterritoriality in late nineteenth- and early twentieth-century Iran, looking at the efforts 
of individuals to escape Qajar legal jurisdiction by claiming the rights of British subjects, and the consequent negotiations between the British-colonial and nascent Iranian-nation-state regimes. The slipperiness of identities and the spaces still available for inter-regime 'forum-shopping', in addition to the languages and forms of documents mobilised for such negotiation, are all indicative of a protracted 'late Persianate.' This era is however decisively brought to a close by the more ambitious Pahlavi regime; Iranian nationality legislation, evolving between the 189os and 1940s, mopped up eligible subjects within and outside the physical boundaries of Iran, closing the doors for flitting in and out of various subjectivities that was the hallmark of Persianate selves. Persian shrank from the marker of a cosmopolis to a national language, even as print media carried the news of that transformation to Persian-reading communities across the former Persianate world.

\section{Acknowledgements}

We are grateful to the European Research Commission and the Lawforms project which provided funding for the organization of the "Transactions and Documentation' workshop held in Exeter 2018. It has been a joy to work with all participants at that workshop and all contributors to this special issue. This essay has been produced and refined through several conversations, and we wish to especially thank Ghulam Nadri, Paolo Sartori, Lyman Stebbins, Elizabeth Thelen and Dominic Vendell for their contributions to the thinking that is presented here. A special thanks to Paolo Sartori for deftly guiding this collection through the process of publication. We thank the European Research Commission and the Lawforms project for providing funds to publish this article, and the entire issue, in Open Access format.

\section{Bibliography}

Alam, Muzaffar. 1986. Crisis of Empire in Mughal North India: Awadh and the Punjab, 1707-1748. Oxford: Oxford University Press.

Alam, Muzaffar. 2004. The Languages of Political Islam: India, 1200-1800. London: Hurst $\&$ Co.

Algar, Hamid. 1994. Persian Literature in Bosnia-Herzegovina. Journal of Islamic Studies 5/2: 254-67.

Amanat, Abbas and Assef Ashraf, ed. 2018. The Persianate World: Rethinking a Shared Sphere. Leiden: Brill. 
Aslanian, Sebouh. 2011. From the Indian Ocean to the Mediterranean: The Global Trade Networks of Armenian Merchants from New Julfa. Berkeley: University of California Press.

Baldwin, James. 2016. Islamic Law and Empire in Ottoman Cairo. Edinburgh: Edinburgh University Press.

Barendse, R.J. 2009. Arabian Seas, 1700-1763. Leiden: Brill.

Bayly, C.A. 1988. Rulers, Townsmen, and Bazaars: North Indian Society in the Age of British Expansion, 1770-1870. New York: Cambridge University Press.

Bayly, C.A. 2001. The Origins of Nationality in South Asia: Patriotism and Ethical Government in the Making of Modern India. Oxford: Oxford University Press.

Beckert, Sven. 2015. Empire of Cotton: A Global History. New York: Vintage Books.

Bishara, Fahad. 2017. A Sea of Debt: Law and Economic Life in the Western Indian Ocean, 1780-1950. Cambridge: Cambridge University Press.

Bishara, Fahad and Hollian Wint. 2021. Into the Bazaar: Indian Ocean Vernaculars in the Age of Global Capitalism. Journal of Global History 16/1: 44-64.

Bose, Sugata. 2006. A Hundred Horizons: The Indian Ocean in the Age of Global Empires. Cambridge, MA: Harvard University Press.

Chatterjee, Nandini. 2020. Negotiating Mughal Law: A Family of Landlords across Three Indian Empires. Cambridge: Cambridge University Press.

Chaudhuri, K.N. 1978. The Trading World of Asia and the East India Company, 1660-1760. Cambridge: Cambridge University Press.

Chaudhuri, K.N. 1985. Trade and Civilisation in the Indian Ocean. Cambridge: Cambridge University Press.

Das Gupta, Ashin. 1979. Indian Merchants and the Decline of Surat, 1700-1750. Wiesbaden: Steiner.

De, Rohit and Robert Travers. 2019. Petitioning and Political Cultures in South Asia: Introduction. Modern Asian Studies 53/1:1-20.

DeWeese, Devin. 2019. Persian and Turkic: From Kazan to Tobolsk. In The Persianate World:The Frontiers of a Eurasian Lingua Franca, ed. Nile Green. Oakland: University of California Press: 131-56.

D'Hubert, Thibaut. 2018. In the Shade of the Golden Palace: Ālāol and Middle Bengali Poetics in Arakan. New York: Oxford University Press, 2018.

Eaton, Richard. 2015. The Rise of Written Vernaculars: The Deccan, 1450-165o. In After Timur Left: Culture and Circulation in Fifteenth-Century North India, ed. Francesca Orsini and Samira Sheikh. Oxford: Oxford University Press.

Eaton, Richard. 2019. India in the Persianate Age, 1000-1765. London: Allen Lane.

Flatt, Emma. 2019. The Courts of the Deccan Sultanates: Living Well in the Persian Cosmopolis. Cambridge: Cambridge University Press.

Fligstein, Neil. 2001. The Architecture of Markets: An Economic Sociology of Twenty-First Century Capitalist Societies. Princeton: Princeton University Press. 
Geertz, Clifford. The Bazaar Economy: Information and Search in Peasant Marketing. The American Economic Review 68/2 (1978): 28-32.

Gommans, Jos J.L. 1995. The Rise of the Indo-Afghan Empire, c. 1710-1780. Leiden: Brill.

Goody, Jack and Watt, I.P. 1963. The Consequences of Literacy. Comparative Studies in Society and History 5: 304-45.

Green, Nile. 2014. Rethinking the "Middle East" after the Oceanic Turn. Comparative Studies of South Asia, Africa, and the Middle East 34/3: 556-64.

Green, Nile, ed. 2019. The Persianate World: The Frontiers of a Eurasian Lingua Franca. Oakland: University of California Press.

Guha, Sumit. 2008. Mārgī, Deśî, and Yāvanī: High Language and Ethnic Speech in Maharashtra. In Märga: Ways of Liberation, Empowerment, and Social Change in Maharashtra, ed. M. Naito, I. Shima, and H. Kotani. New Delhi: Manohar.

Hakala, Walter. 2016. Negotiating Languages: Urdu, Hindi and the Definition of Modern South Asia. New York: Columbia University Press.

Hallaq, Wael B. Sharīa: Theory, Practice, Transformations (Cambridge: Cambridge University, 2009).

Hodgson, Marshall S. 1974. The Venture of Islam. 3 vols. Chicago: Chicago University Press.

Hofmeyr, Isabel. 2012. The Complicating Sea: The Indian Ocean as Method. Comparative Studies of South Asia, Africa, and the Middle East 32/3: 584-9o.

Khazeni, Arash. 2018. Merchants to the Golden City: The Persian Farmān of King Chandrawizaya Raja and the Elephant and Ivory Trade in the Indian Ocean. Iranian Studies: Bulletin of the Society for Iranian Cultural and Social Studies 51/6: 933-945.

Kia, Mana, and Marashi, Afshin. 2016. Introduction: After the Persianate. Comparative Studies of South Asia, Africa, and the Middle East 36/3: 379-83.

Kia, Mana. 2018. Spaces, Sociality, and Sources of Pleasure: A Response to Sanjay Subrahmanyam. Journal of the Economic and Social History of the Orient 61/1-2: 256-76.

Kia, Mana. 2020. Persianate Selves: Memories of Place and Origin Before Nationalism. Redwood City: Stanford University Press.

Kinra, Rajeev. 2007. Fresh Words for a Fresh World: Tãzā-Gū't and the Poetics of Newness in Early Modern Indo-Persian Poetry. Sikh Formations 3/2: 125-49.

Kuran, Timur. 2011. The Long Divergence: How Islamic Law Held Back the Middle East. Princeton: Princeton University Press.

Levi, Scott. 2002. The Indian Diaspora in Central Asia and its Trade, 1550-1900. Leiden: Brill.

Lipartito, Kenneth. 2016. Reassembling the Economic: New Departures in Historical Materialism. American Historical Review 121/1: 101-39.

Mahdavi, Pardis and Arash Khazeni. 2010. Introduction: Trade and Traffic in the Persianate World. Comparative Studies of South Asia, Africa and the Middle East 30/3: 398-40o. 
Markovits, Claude. 2000. The Global World of Indian Merchants, 1750-1947. Cambridge: Cambridge University Press.

Nadri, Ghulam. 2009. Eighteenth Century Gujarat:The Dynamics of Its PoliticalEconomy. Leiden: Brill.

Ng, Su Fang. 2016. The Alexander Romance in Southeast Asia: Wonder, Islam and Knowledge of the World. In Alexander the Great in the Middle Ages: Transcultural Perspectives, ed. Marcus Stock. Toronto: University of Toronto Press: 104-22.

North, Douglass. 199o. Institutions, Institutional Change, and Economic Performance. Cambridge, UK: Cambridge University Press.

Onley, James. 2004. Transnational Merchants in the Nineteenth Century Gulf: The Case of the Safar Family. In Transnational Connections and the Arab Gulf, ed. Madawi alRasheed. London: Routledge.

Orsini, Francesca. 2015. The Multilingual Local in World Literature. Comparative Literature 67/ 4:345-74.

Orsini, Francesca. 2012. How to do multilingual literary history? Lessons from fifteenthand sixteenth-century north India. The Indian Economic and Social History Review 49/2: $225-46$.

Orsini, Francesca and Katherine Butler Schofield, ed. 2015. Tellings and Texts: Music, Literature and Performance in North India. Cambridge, UK: Open Books Publishers.

O'Sullivan, Michael. 2020a. Interest, Usury and the Transition from 'Muslim' to 'Islamic' Banks. International Journal of Middle Eastern Studies. 52/2: 261-87.

O'Sullivan, Michael. 202ob. Paper Currency, Banking and Islamic Monetary Debates in Late Ottoman and Early Saudi Arabia. Journal of the Economic and Social History of the Orient 63/3: 243-85.

Parthasarathi, Prasannan. 2011. Why Europe Grew Rich and Asia Did Not: Global Economic Divergence, 1600-1850. Cambridge, UK: Cambridge University Press.

Perry, John R. 2012. New Persian. In Literacy in the Persianate World, ed. Brian Spooner and William L. Hanaway. Philadelphia: University of Pennsylvania Press: 70-94.

Pickett, James and Paolo Sartori. 2019. From the Archetypical Archive to Cultures of Documentation. Journal of the Economic and Social History of the Orient 62/5-6: 773-98.

Pollock, Sheldon. 2006. The Language of Gods in the World of Men: Sanskrit, Culture and Power in Premodern India. Berkeley: University of California Press.

Prakash, Om. 2004. The Indian Maritime Merchant, 1500-1800. Journal of the Economic and Social History of the Orient 47/3: 435-57.

Prange, Sebastian R. 2018. Monsoon Islam: Trade and Commerce in the Indian Ocean. New York: Columbia University Press.

Raman, Bhavani. 2012. Document Raj: Writing and Scribes in Early Colonial South Asia. Chicago: University of Chicago Press.

Ray, Rajat Kanta. 1995. Asian Capital in the Age of European Domination: The Rise of the Bazaar, 180o-1914. Modern Asian Studies 29/3: 449-554. 
Ricci, Ronit. 2011. Islam Translated: Literature, Conversion and the Arabic Cosmopolis of South and Southeast Asia. Chicago: University of Chicago Press.

Risso, Patricia. 2018. Merchants of Faith: Muslim Commerce and Culture in the Indian Ocean. Curzon: Routledge.

Sartori, Paolo. 2016. Visions of Justice: Sharı̄'a and Cultural Change in Russian Central Asia. Leiden: Brill.

Sood, Gagan. 2016. India and the Islamic Heartlands: An Eighteenth-Century World of Circulation and Exchange. Cambridge: Cambridge University Press.

Spooner, Brian and William L. Hanaway, ed. 2012. Literacy in the Persianate World: Writing and the Social Order. Philadelphia: University of Pennsylvania Press.

Subrahmanyam, Sanjay. 1995. Of Imarat and Tijarat: Asian Merchants and State Power in the Western Indian Ocean, 1400-1750. Comparative Studies in Society and History 37/4: 750-8o.

Subrahmanyam, Sanjay. 2005. Explorations in Connected History: From the Tagus to the Ganges. Oxford: Oxford University Press.

Subramanian, Lakshmi. 1987. Banias and the British: The Role of Indigenous Credit in the Process of Imperial Expansion in Western India in the Second Half of the Eighteenth Century. Modern Asian Studies 21/3: 473-510.

Truschke, Audrey. 2016. Culture of Encounters: Sanskrit at the Mughal Court. New York: Columbia University Press.

Udovitch, Abraham. 1979. Bankers without Banks: Commerce, Banking and Society in the Islamic World of the Middle Ages. In The Dawn of Modern Banking. New Haven: Yale University Press.

Udovitch, Abraham. 1985. Islamic Law and the Social Context of Exchange in the Medieval Middle East. History and Anthropology 1/2: 445-65.

Villiers, Alan. 1948. Some Aspects of the Arab Dhow Trade. Middle East Journal 2/4: 399-416.

Villiers, Alan. 1949. Sons of Sinbad. New York: Charles Scribner's Sons. 